\title{
THE EFFECT OF LEMON (Citrus limon L.) EXTRACT ON MORTALITY OF Aedes sp. AND POTENTIAL AS REPELLENT
}

\author{
Suharno Zen ${ }^{1 *}$, Agus Sutanto ${ }^{1},{ }^{1}$ Afiatur Rohmah \\ ${ }^{12}$ Biology Education Department - Muhammadiyah MetroUniversity \\ *Corresponding author, e-mail: suharnozein@gmail.com
}

\begin{tabular}{|c|c|}
\hline ARTICLE INFO & ABSTRACT \\
\hline \multirow[t]{3}{*}{$\begin{array}{l}\text { Article history } \\
\text { Received } 01^{\text {tt }} \text { of May, } 2020 \\
\text { Revised } 08^{\text {th }} \text { of May, } 2020 \\
\text { Accepted } 10^{\text {th }} \text { of September, } 2020 \\
\text { Published } 12^{\text {th }} \text { of November, } 2020 \\
\text { Keywords } \\
\text { Citrus limon L, } \\
\text { Mortality } \\
\text { Aedes sp. } \\
\text { Protection } \\
\text { Power. }\end{array}$} & $\begin{array}{l}\text { Lemon (Citrus limon L.) is a plant with a peel type that contains } \\
\text { phytochemical compounds namely flavonoids, terpenoids, tannins and } \\
\text { limonenes that can be used as plant-based insecticides. The contents of } \\
\text { these chemical compounds have the ability to kill mosquitoes, and act } \\
\text { as respiratory poisons and stomach poisons for the mosquitoes. The } \\
\text { purpose of this study was to determine the effect of the extract of } \\
\text { lemon peel (Citrus limon L) On the mortality of Aedes sp. and to } \\
\text { determine its potential as a repellent. This type of research used in this } \\
\text { study was an experiment using a completely randomized design study } \\
\text { (CRD) which was carried out using } 3 \text { variations of the treatment dose } \\
\text { of lemon peel extract (Citrus limon L) namely } 25 \%, 27.5 \% \text {, and } 30 \% \\
\text { and controls (+) and (-). Data collection was carried out by looking at } \\
\text { and recording mortality / deaths from Aedes sp. after being given } \\
\text { treatment and observing mosquitoes on the body of mice and counting } \\
\text { the number of mosquitoes that using the Protection Power formula. } \\
\text { Data were statistically tested using One Way Anova and continued } \\
\text { with LSD (Least Significant Difference) test. The results obtained by } \\
\text { the value of Fcount }>\text { table is } 0.484 \text { at the level of } \alpha=0.05 \text { so that H0 } \\
\text { is rejected and H1 is accepted. This means that there is a significant } \\
\text { influence of each treatment. The best effective dose is } 30 \% \text { with } 50 \\
\text { mosquitoes dead. The highest protection power at a concentration of } \\
30 \% \text { was } 97.3 \% \text {, while the lowest protective power at a concentration } \\
\text { of } 25 \% \text { was } 77.1 \% \text {. }\end{array}$ \\
\hline & $\begin{array}{l}\text { Copyright (@) 2020, Zen et al., } \\
\text { This is an open access article under the CC-BY-SA license }\end{array}$ \\
\hline & (C) ${ }_{\mathrm{BY}} \mathrm{SA}_{\mathrm{H}}$ \\
\hline
\end{tabular}

\section{A. INTRODUCTION}

Dengue Hemorrhagic Fever (DHF) is a disease caused by dengue viruses I, II, III, and IV, and is transmitted through vector intermediaries of the mosquitoes Aedes aegypti and Aedes albopictus and is still one of the health problems for the community in Indonesia (Soegijanto, 2009). DHF disease is influenced by environmental conditions, population mobility, population density, the presence of artificial or natural containers in landfills (TPA) or in other trash cans. The Indonesian Ministry of Health (2017) states that 
there have been 17,877 cases in Indonesia from January-May with 115 deaths with an Incidence Rate (IR) of 78.85/100,000 population which exceeds the national IR target of 49/100,000 population. Lampung Province also experienced dengue cases in the same year, with a total of 2,908 cases and 9 deaths with an Incidence Rate (IR) of 35.08/100,000 population. The Metro City Health Office (2018) states that Metro City is an endemic area for the Dengue Hemorrhagic Fever (DHF) epidemic with a total of 83 cases occurring in 2017, which is certainly a polemic for the surrounding community.

Prevention efforts that have been carried out have been more directed at controlling the vector of the spreader by making efforts to prevent mosquito bites, which generally use spray and mosquito coils and use repellents (Zen \& Asih, 2017). These efforts are generally carried out by using synthetic or synthetic chemical insecticides which have a negative impact if used continuously because they affect body health and can damage the environment. The use of botanical insecticides by utilizing compounds contained in plants is an alternative in reducing the negative impact of using synthetic insecticides. Use of repellents. Considered practical, because it is simply applied to the skin surface of the body concerned. Repellent is said to be good if used by the body and does not cause hypersensitivity and allergic reactions. Repellents can be made from chemicals or natural ingredients. The use of repellent generally does not immediately kill insects, but rather functions to repel the presence of insects, mainly due to their strong smell (Novizan, 2002). Repellents that are widely used by the public to repel insects are synthetic repellents which are synthesized in the laboratory. An example of such synthetic repellents is DEET N, Ndiethyl-m-toluamide which is used to repel mosquitoes. Given that the use of synthetic repellents has many negative effects, it is necessary to replace them. Repeated use of chemicals will cause new problems, namely killing non-target insects (Widiyanti et al., 2004), disrupting the quality and balance of the environment due to residues, the emergence of resistance in target animals (Novizan, 2002), and contamination of gardens. Vegetables and fruit, and environmental pollution (North Dakota State University, 1991).

Based on this, the search for natural compounds that can be used as repellents is prioritized as safe and environmentally friendly alternatives derived from plants. Several types of plants that have been inventoried in previous studies by researchers have the potential to be mosquito repellents, such as citronella, geranium, eucalyptus, cinnamon, rosemary, basil, garlic and others. The bioinsecticide repellent is expected to assist the government in suppressing and controlling the vector mosquito population because it is biodegradable in nature, so it does not pollute the environment and is relatively safe for humans. In addition, bioinsecticides must also be selective against organisms (Kardinan, 2004).

\section{B. METHOD}

1. Time and Place of Research

This research was conducted in August 2018 - October 2018 at the Integrated Science Laboratory of Muhammadiyah Metro University.

2. Research Tools and Materials

The tools and ingredients in this research are balance, glass beaker, spatula, mortar, lemon orange peel, cleansing milk, mosquito cage, sprayer, label, cotton, rubber, paper 
cup, aspirator, trap. The materials used in this study were lime peel extract concentrations of $15 \%, 30 \%, 60 \%, 96 \%$ ethanol, and female Aedes sp

3. Research Methods

This study uses quantitative research methods using a pure experimental approach (true experiment) with a completely randomized design (CRD) to determine the effect of several treatments on mosquito mortality. The sample in this study was the Aedes sp mosquito which was obtained from the trap culture in the Integrated Science Laboratory of Muhammadiyah Metro University, while the lemon orange peel extract was obtained from a maceration process made in the Organic Chemistry Laboratory of the University of Lampung. The research was conducted by giving treatment to the Aedes sp. by spraying 3 doses of lemon peel extract (Citrus limon L), namely 25\%, 27.5\% and 30\% with control $(+)$ and (-) treatments. Each treatment in this study was repeated 5 times with a sample of 10 individuals for each repetition and carried out for 24 hours with a time interval of 2 hours.

4. Data Collection and Analysis

The data was collected by calculating the number and percentage of mortality of Aedes sp. from each treatment that has been given to obtain data on the mortality rate of Aedes sp mosquitoes for 24 hours. Data collection was also carried out with a protective power to observe mosquitoes that land on mice and calculate the number of mosquitoes that land using the Power Protection formula according to Kardinan (2006), namely:

Percentage of protection power $(100 \%)=\left(\frac{\sum C-\sum T}{\sum C}\right) \times 100 \%$

Information:

$\mathrm{C}=$ number of contact mosquitoes in control

$\mathrm{T}=$ number of contact mosquitoes in treatment

\section{RESULTS AND DISCUSSION}

Based on the research results, the effect of lemon peel extract on the mortality of Aedes sp. After treatment for 1-24 hours with intervals of 2 hours can be seen in the following Figure 3.1:

Mortalitas Nyamuk Aedes sp. (\%)

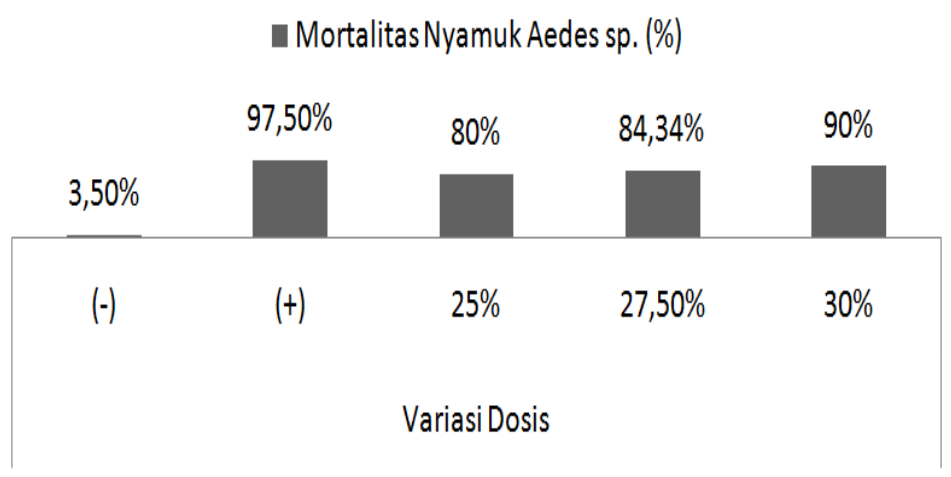

Figure 3.1. Mortality of Aedes sp 
While the protective power after treatment can be seen in the following Table 3.1.

Table 3.1. Percentage of Aedes sp. after being given treatment within $\mathbf{3 0}$ minutes

\begin{tabular}{c|c|c|c|c|c}
\hline \multirow{2}{*}{ Deuteronomy } & \multicolumn{5}{|c}{ Protection Power of Adult Aedes sp } \\
\cline { 2 - 6 } & Kontrol (-) & Kontrol (+) & $25 \%$ & $27,50 \%$ & $30 \%$ \\
\hline U1 & $0 \%$ & $100 \%$ & $75 \%$ & $80 \%$ & $95 \%$ \\
\hline U2 & $0 \%$ & $100 \%$ & $78 \%$ & $88 \%$ & $97 \%$ \\
\hline U3 & $0 \%$ & $100 \%$ & $78,5 \%$ & $90 \%$ & $100 \%$ \\
\hline Total & $0 \%$ & $300 \%$ & $143.3 \%$ & $213.3 \%$ & $266.6 \%$ \\
\hline Average & $0 \%$ & $100 \%$ & $77,1 \%$ & $86 \%$ & $97,3 \%$ \\
\hline
\end{tabular}

Based on the diagram above, the control (-) concentration of $0 \%$ for each repetition shows the protection power of each repetition of $0 \%$, it shows that there is no repellent effect on the protective power of Aedes sp sp. Mosquitoes so that there are still mosquitoes that land. In the control treatment (+) the concentration of $0 \%$ each repetition showed $100 \%$, meaning that the repellent in the control treatment $(+)$ showed that there was a repellent effect on the protective power of Aedes sp so that no mosquitoes landed.

Furthermore, the protective power of the Aedes sp mosquito in the treatment of a concentration of $25 \%$ with 3 replications, it was seen that the percentage of protective power in the first repetition was $75 \%$, the protective power of the second repetition was $78 \%$ and the protective power in the third repeat was $78.5 \%$. The protective power of Aedes sp in the treatment concentration was $27.5 \%$ with 3 replications, it was seen that the percentage of protection power was $80 \%$, the second replication was $88 \%$ and in the third replication $90 \%$. The protective power of Aedes sp mosquitoes at a concentration of $30 \%$ treatment was seen to have the highest protection power in the 3rd replication which was $100 \%$.

Based on the percentage of the protective power of Aedes sp. can be seen in Figure 3.2 as follows:

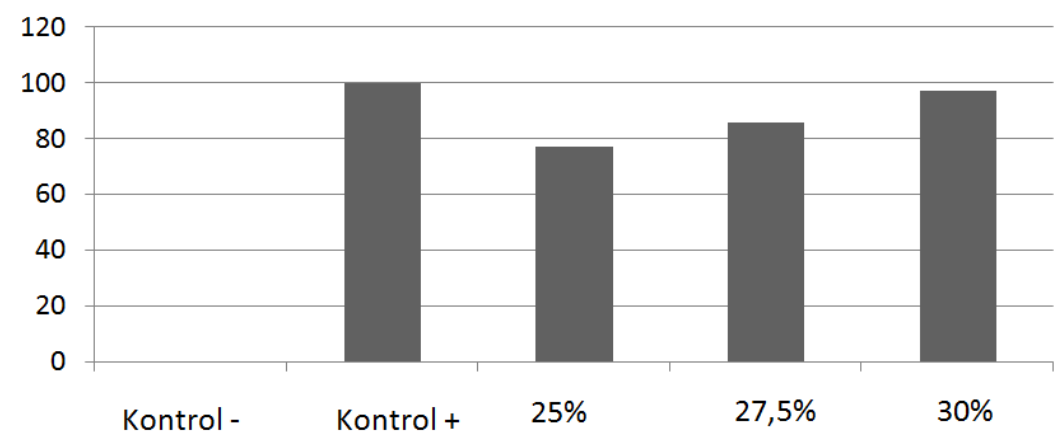

Figure 3.2. Diagram of Average Protection Power for Aedes sp.

Based on the picture above, it can be seen that the average percentage value of protection power in the control treatment $(+) 0 \%$ protection power is $100 \%$. This means that no mosquitoes perch on the body of the test animal (mice). In the control treatment (-) $0 \%$ the protection power is $0 \%$. This means that there are still mosquitoes that land on the mice. In the $25 \%$ concentration treatment, the protective power was $77.1 \%$. In the treatment concentration of $27.5 \%$ the protective power was $86 \%$. While the latter in the treatment with a concentration of $30 \%$, the protection power was $97.3 \%$. The percentage of this figure indicates that almost no mosquitoes perch in this treatment. Of the 30 mosquitoes used for 
this treatment, only one mosquito perched on the body of the mice. This means that the $30 \%$ concentration treatment indicates the best protective power of Aedes sp to be recommended as Aedes sp high, namely at a concentration of $30 \%$ of $97.3 \%$.

Based on the bar chart above, it is known that there are clear differences in the respective dosage treatments used. The control treatment (-) was carried out by spraying pure distilled water without adding any extract so that it had the least mortality yield of $3.5 \%$, which means that there were still $96.5 \%$ of Aedes sp. the living. This happens because distilled water does not have any compounds that can act as toxic or poisonous to Aedes sp. The control (+) treatment was carried out by using a synthetic insecticide with the brand "Baygon" which was known to have the highest mortality percentage, which was $97.5 \%$. Baygon is a type of synthetic insecticide which contains $0.125 \%$ of the active compound in the form of D-phenotrin and $0.100 \%$ praletin while the other $99.75 \%$ is equipped with additives. The active compound is part of the household insecticide pyrethroid type which is the most widely used in coil and spray insecticides. The level of effectiveness in eradicating insects is very effective so that the mortality of Aedes mosquitoes increases. In this treatment, this treatment is the result with the highest percentage number compared to others. However, these compounds are classified as compounds with the type of synthesis which if used in the long term and continuously will have a negative impact.

Treatment with a dose of $25 \%$ is a treatment with a dose containing the lowest lemon peel extract used and can eradicate mosquitoes with a mortality percentage of $80 \%$. The dose of $27.5 \%$ was the treatment dose which was $2.5 \%$ higher than the lower dose and resulted in a total mortality of $84.34 \%$ and a dose of $30 \%$ which resulted in a total mortality of $90 \%$. Ability to kill mosquitoes Aedes sp. This is done by the lemon orange skin extract because the content of the extract is in the form of Limonene, Tannins, Flavonoids and Terpenoids. This chemical compound is a combination of chemical compounds which, if used for insects, will act as toxic or poison, in this case, as a respiratory poison. The variation in the dosage of the lemon peel extract used will affect the amount of chemical compounds contained therein. So that the greater the dose used, the more chemical compounds that play a role and affect the mortality time of the Aedes sp. Mosquito. If the control treatment does not use a mixture of lemon peel extract then there is absolutely no chemical compound in it, and it will not affect the mortality of Aedes sp.

The mechanism of the Aedes sp. received treatment giving lemon peel extract explained by Zen \& Asih, (2017) in a similar study using Kotok Dung extract which states that insects detect stimuli through their sensors (olfactory) which are generally responsive to chemical stimuli (distinctive odors). The higher the odor concentration, the more responsive the insect will be. The insect will try to respond and try to get closer (attract) and away (repeal) from the source of the stimulation if it is considered dangerous and unwelcome. When the insect is unable or avoiding it, the insect will experience a knock down which is permanent (followed by death) or temporary (reversible) where the insect will recover for some time. The administration of lemon peel extract In this study experienced a permanent knock down (and was followed by death) due to the Aedes sp. Mosquito. Unable to avoid stimulation sources that contain a lot of chemical substances. 
Lemon peel extract Acts as a respiratory poison through the process of damaging the nerves in the body of the mosquito Aedes sp. According to Zen \& Asih, (2017) it is stated that the characteristic odor molecules of chemical compounds will enter extracellularly and are then captured by chemoreceptors on cilia located in the mosquito antenna. The odor molecules will then be linked to OBPs (Odoran Binding Receptors) and then carried by the OBPs through the lymph fluid in the cilia to the olfactory receptor neurons (ORNs). In addition to carrying these chemical compound molecules (odor molecules), OBPs are able to dissolve chemical compound molecules and select these molecules to be accepted in certain Ors (olfactory receptors). Subsequent odor molecules A with G-protein couple extracellular receptors on Ors located in specific dendrites (ORNs), where alternately the intracellular G-protein couple activates and results in changes to the G-protein conformation. This will result in nerve depolarization which will cause an electrical crisis to the lobe and accumulate with acetylcholine in the nervous system, resulting in nerve damage and death.

The extract of lemon peel contains various chemical compounds which act as bioinsecticides and can lead to death in mosquitoes Aedes sp. These chemical compounds are explained by Yeni (2008) which states that bioinsecticide compounds consisting of flavonoids, saponins, alkaloids, and tannins are plant defense chemical compounds that are included in secondary metabolites originating in plant tissues and can become stomach poisons and respiratory toxins when it enters the body of the mosquito Aedes sp. Musdalifah (2016) states that saponins are included in terpenoid compounds, if ingested by insects there will be activity in the insect's body by binding free sterols in the digestive tract of food where the sterol itself is a substance that functions as a a precursor to the hormone ekdison, so that the decreasing number of free sterols in the insect's body will result in disruption of the moulting process in insects. In addition, saponins also destroy red blood grains and are toxic to cold-blooded animals. Tannin compounds are compounds that can produce complex compounds through the interaction of tannins with proteins that are toxic or toxic so that they can play a role in inhibiting growth and reducing insect appetite through inhibition of digestive enzyme activity (Ningsi et al., 2016). Flavonoids are chemical compounds contained in the extract of lemon zest which act as respiratory inhibitors in the Aedes sp. When the Aedes sp. breathing, flavonoids will enter with air (O2) through the breathing apparatus and inhibit the respiratory work system in the mosquito's body (Iftita, 2016). Flavonoids attack the nerves in several vital organs of insects, causing nerve weakness such as breathing and causing death (Musdalifah, 2016).

Based on the standard of efficacy from the Pesticide Commission of the Ministry of Agriculture (2012), the anti-mosquito agent has a protective power effectiveness of $90 \%$ for 6 hours. So the repellent of lemon peel has met these standards because the protective power in the $30 \%$ concentration treatment is $97.3 \%$. Thus, lemon peel has the potential / alternative effort as a natural repellent against Aedessp mosquitoes which is relatively safe for humans and environmentally friendly because there is no residue left behind. This effort is an integral part of the Integrated Mosquito Management (IMM) program (Ghosh et al., 2012). Where in the vector control strategy, the principles of security, effectiveness, rationality and sustainability are very concerned and environmentally friendly (Kalita et al., 2013). 


\section{CONCLUSION}

From the results of this study it can be concluded that:

1. There is a significant effect of lemon peel extract (Citrus limon L) On the mortality of Aedes mosquitoes sp at a dose of $30 \%$ mosquitoes mortal / dead, and protection power at a dose of $30 \%$ as much as $97.3 \%$ of mosquitoes do not want to land.

2. Lemon peel extract has the potential to act as a repellent against the Aedes sp. Mosquito, which is relatively safe and environmentally friendly.

\section{E. REFERENCES}

Ghosh, A., Chowdhury, N., \& Chandra, G. (2012). Plant extracts as potential mosquito larvicides. In Indian Journal of Medical Research (Vol. 135, Issue 5, pp. 581-598).

Iftita, F. 2016. Uji Efektivitas Rendaman Daun Singkong (Manihot Utilissima) Sebagai Insektisida Terhadap Nyamuk Aedes Aegypti Dengan Metode Elektrik Cair. Jurnal Kesehatan Masyarakat (E-Journal), 4(2), 20-28.

Kalita, B., Bora, S., \& Sharma, A. K. (2013). Plant Essential Oils As Mosquito Repellent-a Review. International Journal of Research and Development in Pharmacy and Life Sciences, 3(1), 741-747.

Komisi Pestisida Departemen Pertanian. 2012. Metode Standar Pengujian Efikasi Pestisida. Departemen Pertanian. Jakarta.

Musdalifah. 2016. Uji Efektivitas Ekstrak Kulit Buah Jeruk Nipis (Citrus aurantifolia) Sebagai Insektisida Hayati Terhadap Nyamuk Aedes aegypti. Skripsi tidak Diterbitkan. Fakultas Kedokteran dan Ilmu Kesehatan. UIN Alauddin Makassar.

Ningsi, Wilda E., Yuniar N., Fachlevy A. F. 2016. Efektivitas Uji Daya Bunuh Ekstrak Daun Pepaya (Carica papaya L.) Terhadap Larva Nyamuk Anopheles aconitus Donits dalam Upaya Pencegahan Penyakit Malaria di Daerah Persawahan Desa Lalonggombu Kecamatan Andolo Kabupaten Konawe Selatan. Fakultas Kesehatan Masyarakat. Universitas Halu Oleo.

Ningsi. 2017. Data dan Informasi Profil Kesehatan Indonesia. Kementerian Kesehatan Republik Indonesia.

Ningsi. 2018. Profil Kesehatan Kota Metro 2017. Dinas Kesehatan Kota Metro.

Soegijanto, S. 2009. Kumpulan Makalah Penyakit Tropis Dan Tropis Di Indonesia. Surabaya: Airlangga Press.

Yeni. 2008. Efektivitas Ekstrak Daun Babandotan (Ageratum conyzoides Linn.) terhadap Larva Anopheles sundaicus Linn. Di Desa Babakan Pangandaran Jawa Barat. Laporan Kerja Praktik. Jurusan Biologi FMIPA Universitas Lampung. Bandar Lampung.

Zen, S., \& Asih, T. (2017). Potensi Ekstrak Bunga Tahi Kotok (Tagetes Erecta) Sebagai Repellent Terhadap Nyamuk Aedes Aegypti Yang Aman Dan Ramah Lingkungan. $\begin{array}{lllll}\text { BIOEDUKASI (Jurnal Pendidikan Biologi), } & \text { 8(2), }\end{array}$ https://doi.org/10.24127/bioedukasi.v8i2.1072 